\title{
CYPRÆA ZEBRA.
}

\section{$* * * * * * * * * * * * * * * * * *$ \\ CHARACTER GENERICUS.}

Animal Limax.

Testa univalvis, involuta, subovata, obtusa, lævis.

Apertum utrinque effusa, linearis, utrinque dentata, longitudinalis.

Lin. Syst. Nat. Gmel. p. 3397.

CHARACTER SPECIFICUS, EंC.

CYPRÆA turbinata cinerea, fasciis latis violaceo-fuscis.

CYPR AA ZEBRA. C. testa turbinata cinerea, fasciis fuscis.

$$
\text { Lin. Syst. Nat. p. } 1174 .
$$

CYPR $Æ A$ testa turbinata cinerea, fasciis latis griseis, aperturæ denticulis fuscis.

Born Test. Mus. Cas. Vind. p. 176.

t. 8. f. 3 .

In maribus Indicis præcipue conspicitur elegantissima hæc cochlea, coloribus interdum varians: in opere Bornii exhibetur pulchrum specimen in tabula depictum. 




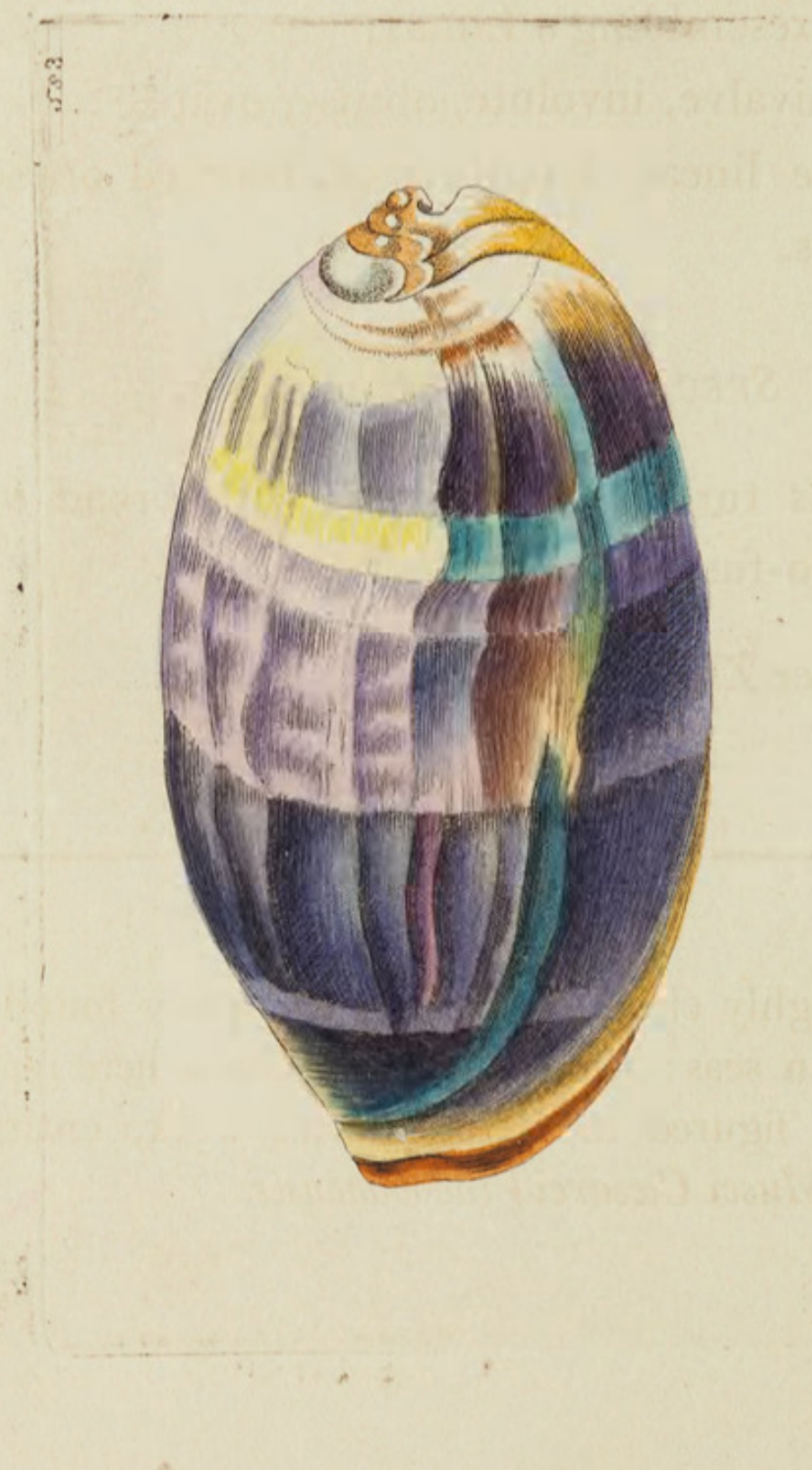




\section{ZEBRA COWRY.}

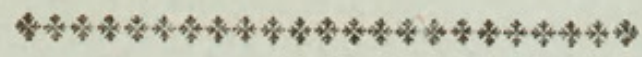

\section{GENERIC CHARACTER.}

Animal resembling a Limax.

Shell univalve, involute, obtuse, ovate.

Aperture linear, longitudinal, toothed on both sides.

SPECIFIC CHARACTER, EC.

Cinereous turbinated Cypræa, with broad violaceo-fuscous bands.

The larger ZEBRA COWRY.

This highly elegant shell is principally found in the Indian seas: the beautiful specimen here represented is figured in Baron Born's work, entitled Testacea Musei Ccesarei Vindobonensis. 


\section{$2 \mathrm{BHL}$ Biodiversity Heritage Library}

Shaw, George. 1803. "The Zebra Cowry, Cypræa zebra [PI. 583]." The Naturalist's Miscellany 14(CLXVII), https://doi.org/10.5962/p.311026.

View This Item Online: https://www.biodiversitylibrary.org/item/278723

DOI: https://doi.org/10.5962/p.311026

Permalink: https://www.biodiversitylibrary.org/partpdf/311026

\section{Holding Institution}

Museums Victoria

\section{Sponsored by}

Atlas of Living Australia

\section{Copyright \& Reuse}

Copyright Status: Public domain. The BHL considers that this work is no longer under copyright protection.

This document was created from content at the Biodiversity Heritage Library, the world's largest open access digital library for biodiversity literature and archives. Visit BHL at https://www.biodiversitylibrary.org. 